\title{
Solarisation Piles and their Impact on the Removal of Pathogenic Microorganisms
}

\author{
Alain Buendía Garcia', Enrique Salazar-Sosa ${ }^{3}$, Miguel A. Gllegos Robles², Jesus Luna Anguiano ${ }^{5}$, Ana A. Valenzuela Garcia², Miguel A. Urbina \\ Martinez ${ }^{4}$
}

1 Juarez University of the State of Durango, Gómez Palacio, Mexico

2 Juarez University of the State of Durango, Gómez Palacio, Dgo, Mexico

${ }^{3}$ Technological Institute of Torreón, Ejido Anna, Torreón, Coahuila, Mexico

${ }^{4} U A A A N$, Torreon Coahuila, Mexico

${ }^{5}$ Universidad Politecnica de Gomez Palacio, Durango. Mexico

\begin{abstract}
The main objective of the research was to demonstrate the increment of temperature and good pathogen control with solarized cow manures. In order to corroborate which of the treatments was the one that produced the highest temperature and eliminated pathogen microorganisms present (fungi-bacteria). The distribution of the treatments in the field was carried out using a randomized design of blocks, with four replications. Temperatures in the different treatments and repetitions of manure piles were sampled. The temperatures were recorded by means of analog thermometers at two different operating depths (0-7.5 and 7.5-15). The temperatures showed a behavior with a greater oscillation with a centre orientation to the right of the pile of manure, placing in these orientations the maximum temperatures and the minimum temperatures were oriented in the lower left part of the pile, but solarisation piles shown very good increment of temperatures with values higher to $60^{\circ} \mathrm{C}$ so these temperatures are very good to pathogens control. In another way the results shown the presence of Escherichia coli, F. interobacteriaceae, Enterobacter sp., Bacillus sp., Mucor sp. and $F$. saccharomycetaceae, were found in manure without solarizing (control). Also Giardia and Crptosporidium were found in the T additional experimental unit and removal after solarisation process.
\end{abstract}

Keywords: Pathogen; Solarisation; Fungi; Bacteria

\section{Introduction}

At the national level, the 2002 livestock inventory indicates that there were almost 30 million heads of cattle for meat and just over two million head of milk cattle production. Most beef production for meat occurs extensively in life stock, so there is no confined production of manure. Only in the case of dairy cattle, a manure production of 3.8 million $t$ year is estimated [1]. In the Comarca Lagunera this livestock generates around 2.6 million $\mathrm{kg}$ (dray matter) per day [2].

The organic waste excreted by mammals is commonly known as manure. Manure is generally composed of undigested food waste, water, organisms of different types and contents, as well as urine and forage residues. This material is produced in large quantities in cattle farms of beef and milk established under the extensive production system. These animals produce important quantities of manure, in milk cattle it is estimated that they generate around 2.6 million $\mathrm{Kg}$ per day in the Lagunera Region of Coahuila and Durango based on dry matter (DM) [2]. In this Region, the common practice is the application of bovine manure to the soil, prior to the sowing of forage crops, with the purpose of improving its physical structure, the productive capacity of the same.

The manure contains organic compounds of easy decomposition, when manure is incorporated into the soil, the biological activity is increased, the physical and chemical properties of the soil, the availability of nutrients for the plants is increased [3-6] these conditions are influenced by factors such as temperature, soil moisture, soil aeration, $\mathrm{C} / \mathrm{N}$ ratio (carbon/nitrogen) and proper handling of manure doses. In the Comarca Lagunera manure is highly saline (20-50 kg of salt per ton of dry manure base) due to the nutritional quality of the diets provided to dairy cattle, which is why care must be taken in the management and application of doses since the crop should only be applied what is required for its nutrition. The manure is composed of solid material (excrement) and liquid (urine), in solid excrement we find $25 \%$ or more of nitrogen and this when it is synthesized protein and applied to the soil is quickly destroyed and used by the plants, The nutrients that it contains and that have been digested and excreted by the animal are soluble and directly utilizable by the plants. Many factors influence the amount and composition of production in manure; such as the class, age, conditions, milk produced or work done on the animal and the kind and amount of food consumed. A more digestible food is greater the proportion of nutrients for plants [7].

The manure for soils deficient in organic matter is a magnificent improver of physical conditions, the benefit is observed in the long term since mineralization accumulates over the years due to the residual effect [8]. Therefore the objectives of this study were determine the effectiveness of solarisation of manure in different treatments, in order to know the most feasible, considering the conditions of depth, humidity and microorganisms.

-Determine the behavior of the temperature in the different piles of manure.

-Determine the effect of solarisation on microorganisms in manure piles, compared to untreated manure. Organic agriculture.

*Corresponding author: Enrique Salazar-Sosa, Technological Institute of Torreón. Ejido Anna, Torreón, Coahuila, Mexico, Tel: +528717507199; E-mail: enmagel1@yahoo.es

Received January 28, 2018; Accepted February 20, 2018; Published February 28 2018

Citation: Garcia AB, Salazar-Sosa E, Robles MAG, Anguiano JL, Garcia AAV et al. (2018) Solarisation Piles and their Impact on the Removal of Pathogenic Microorganisms. Agrotechnology 7: 176. doi: 10.4172/2168-9881.1000176

Copyright: $\odot 2018$ Garcia AB, et al. This is an open-access article distributed under the terms of the Creative Commons Attribution License, which permits unrestricted use, distribution, and reproduction in any medium, provided the original author and source are credited. 


\section{Literature Review}

\section{Organic agriculture}

It can be defined as an agricultural production system that, formulated with an ecological basis, avoids the use of synthetic products such as chemical fertilizers, pesticides, herbicides and others that can cause contamination of food or the ecosystem. Organic food is that derived from the practices used by organic agriculture and that during all its subsequent production and processing process, has been free of synthetic chemicals. Organic farming systems depend on crop rotation, recycling of plant waste, use of animal manure, legumes, green manures, composted organic waste and mineral rocks, along with the biological control of pests and diseases [9].

\section{Composition of fertilizers and fertilizers}

Organic fertilizers are very different from chemical or mineral fertilizers; the basic difference is that they contain organic matter. Due to their content of organic matter they are a slow source of food and provide several nutrients simultaneously; however, they improve mainly the quality of the soil.

\section{Organic fertilizers}

Organic fertilizers constitute a very diverse group of materials from more or less transformed animal and vegetable waste and which have high organic matter contents. Among these may be mentioned the following: [10,11].

Solid manure: It is composed mainly of domestic animal excrement and a small amount of urine and straw. It contains organic $\mathrm{N}$ and ammonia, phosphorus, potassium and micronutrients such as $\mathrm{Cu}, \mathrm{Zn}, \mathrm{Fe}$ and $\mathrm{Mn}$.

Liquid manure: slurry is made up of fermented urine from domestic animals, mixed with particles of excrement, juices that flow from manure and rainwater. Due to its important content in potassium salts, the slurry is considered as an N-K fertilizer. It is a fast-acting fertilizer, since the nutrients it contains are mostly in readily available form. The application in high doses of liquid waste can lead to soil salinization.

Semi-liquid manure: It is a mixture of excrement and urine, to which water is added to facilitate its transport and distribution.

Straw: Straw is poor in nutrients, but it supplies degradable organic matter, for example cellulose, which is an energy source. Since the decomposition of straw is slow, it must be buried well in advance of sowing.

Earthworm humus: It is called Worm Humus, the product of the ingestion and digestion of organic waste, prepared as food for certain types of earthworms.

Compost: It is a decomposition product of vegetable and animal waste, with various additives. This group is the largest of organic fertilizers; it ranges from materials without any quality, from the garbage dumps, to perfectly prepared substrates with high fertilizing power.

\section{Manure}

Manure and other organic waste are the main fertilizers used in organic agriculture. These natural organic residues are also widely used in conventional agriculture along with chemically synthesized fertilizers. Microbiological contamination derives from the use of natural fertilizers and the necessary measures to address them should be oriented to both organic and conventional agriculture [12].

Chemical composition of manure and other organic fertilizers: The composition of the manure is very variable, since it depends on many factors such as the species, age and feeding of the cattle, as well as the use of beds, the inclusion or exclusion of the liquid excrement and the magnitude of the decomposition and washing processes that have occurred during storage [13]. The chemical composition of the manures varies according to the diet of the livestock. However, nitrogen is the most abundant nutrients found in most manure (Table 1).

Dosage of application of organic waste: The amount of manure that is incorporated into agricultural land is variable and fluctuates between 40 to 300 ton $\mathrm{ha}^{-1}$. If we consider that the salt content of manure in the lagoon is 20 to $50 \mathrm{~kg} \mathrm{ton}^{-1}$ the effect of salinity of the soils and even more on the sodicity of the same is already a serious problem in the region, so dosing Properly manure for years and between years is a necessity in the region [14-16] A sustainable manure management system should include the following objectives:

\section{Pathogenic microorganisms present in manure}

Coprophilous fungi: Fungi are a group of organisms currently classified in the fungus kingdom. Herrera and Ulloa defines fungi as eukaryotic organism, without chlorophyll, heterotrophs, almost always carriers of spores, which varies from amoeboid to plasmodial (without cell wall) from unicellular to filamentous [17] The coprophilous fungi are derived from the Latin words Fimus=Manure, mud, nutrient-rich mud and Incan=Greek inhabitant or neighbour. Copros=Excrement and Filos=Friend, these fungi develop in both manure from herbivores, omnivores or carnivores or on substrates fertilized with manure [18].

Bacteria: The entire haemorrhagic bacteria Escherichia coli was first identified as a human pathogen in 1982 [19]. Most of the affectations in humans due to pathogens are attributed to the consumption of foods infected with Escherichia coli bacteria as the main source of contamination. Even though the bacterium is more prevalent in the flesh of infected animals, this situation has been related to contact between sick animals, or to the acquisition of the bacteria in the waste of the slurry (manure and water). The main factors that determine the survival of Escherichia coli under natural conditions are: the soil-manure ratio, the temperature of the soil and the soil-dwelling organisms that antagonize the bacteria.

\section{Treatments to reduce the risks associated with manure}

The use of untreated animal manure in the production of edible plant products results in a greater risk of contamination than the use of treated manure and, therefore, the application of untreated manure is not recommended. Although untreated manure is not recommended for use as fertilizer, it is used in some regions. In this case, it must be added to the soil during the preparation of the soil and before sowing. It is necessary to let the maximum time pass between the application of manure and planting. The manure must be incorporated into the soil and the soil removed periodically to facilitate the reduction of

\begin{tabular}{|c|c|c|c|c|}
\hline Nutrients & Cattle manure & Chicken manure & Pig manure & Manure sheep \\
\hline Nitrogen & 2.8 & 05-Aug & 03-May & 03-May \\
\hline Phosphorus & $0.2-1.0$ & 01-Feb & 0.5-1.0 & 0.4-0.8 \\
\hline Potassium & 01-Mar & 01-Feb & 01-Feb & 02-Mar \\
\hline Magnesium & 1.0-1.5 & 02-Mar & 02-Mar & 0.2 \\
\hline \multicolumn{4}{|c|}{ Table 1: Composition of manure of different species. }
\end{tabular}


Citation: Garcia AB, Salazar-Sosa E, Robles MAG, Anguiano JL, Garcia AAV, et al. (2018) Solarisation Piles and their Impact on the Removal of Pathogenic Microorganisms. Agrotechnology 7: 176. doi: 10.4172/2168-9881.1000176

Page 3 of 7

pathogens. The amount of time that pathogenic bacteria can survive in manure is unknown, but some researchers estimate that depending on environmental conditions, the survival period can reach a year or more. It is not recommended to add untreated animal manure in the fields during the growing period [20].

Passive treatments: Passive treatments are based on the maintenance of organic waste under natural conditions. The piles of fertilizer are not removed and the free oxygen present in them is used quickly, giving rise to anaerobic conditions that delay the process of transformation into compost. However, environmental factors such as temperature, humidity and ultraviolet radiation, when they act with sufficient time, inhibit the growth of pathogenic organisms and eventually destroy them. The biggest obstacle faced by this method is that it takes too much time to significantly reduce the number of pathogens in the organic matter and it is difficult to determine the time necessary for this process to take place. The amount of time needed depends on the climate, the region, season of the year; as well as the origin, the type of manure and the organic matter used. Due to these variables, passive transformation is not recommended [21-24].

Active treatments: Active treatments are those in which the piles of organic matter are treated under conditions that accelerate the process of transforming the waste into fertilizers. The active treatment to transformorganic matter into fertilizer is the most used by farmers. In the active treatments, the piles of organic matter are removed frequently or they are supplied with another type of aeration in order to maintain adequate oxygen (aerobic) conditions inside the pile.

The temperature and humidity levels are controlled and necessary supplements are added to maintain optimal humidity and an adequate carbon/nitrogen rate to complete the process of composting. Normativity in the use of organic waste Legislation on livestock waste in Mexico, the General Law of Ecological Balance and Environmental Protection (LGEEPA) in relation to pollution by agricultural activities (use of herbicides, insecticides, chemical fertilizers) and livestock (slurry, livestock excrement diluted) among others, the soil and surface and groundwater, its attention to these problems is practically null. In Mexico, there is an Official Mexican Standard NOM-037 for the specifications of the process of production and processing of organic agricultural products. There are 15 Certification Agencies registered, of which 3 are of Mexican origin [23,24] and an international agency (OCIA), Mexico division [25].

In our country the production of organic products is governed by the Official Mexican Standard NOM-307-Fito-1995/1997, which establishes the specifications of the production and processing process of organic agricultural products, although organic production and commercialization has State inserted in the international market through certification and intermediary companies of industrialized countries that have set the guidelines for domestic products and for export.

\section{Materials and Methods}

\section{Location of the study area}

The present experiment was developed in 2015 "Ejido Fresno del Norte", located at Km 26 Carretera Torreón to Francisco I. Madero, Coahuila, which was established under two stages:

Laboratory conditions: The laboratory work to determine microorganisms (fungi, bacteria, giardia and criptosporidium) was carried out in the microbiology laboratory of the Higher School of
Biology of the Juarez University of the State of Durango, (ESB-UJED), which is located at Av. Universidad S/N Fraccionamiento Filadelfia, Gómez Palacio, Dgo.

Field conditions: Subsequently, nine treatments were established to solarize the bovine manure, using transparent plastic padding to raise the temperatures in it $[26,27]$ in order to corroborate which of the treatments was the one that produced the highest temperature and eliminated pathogen microorganisms present (fungi-bacteria and protozoan). An experimental random block design with four repetitions was used placing the following Factors (Table 2) Combination between factors gave nine treatments and with the four replications resulted with 36 experimental units (Tables 3 and 4).

\section{Solarisation method}

To increase the temperature in manure piles, the solarisation method was used, which consists of subjecting the treatments to extreme temperatures, through the use of plastic covers and the sun's rays [28]. The manure was donated by the stables of Ejido Fresno del Norte and was subjected to the process of solarisation during the summer, autumn and winter throughout the year. The manure was stacked in mounds or piles with dimensions of 2 meters long by $1.5 \mathrm{~m}$ wide and $1.0 \mathrm{~m}$ high. The batteries were covered with plastic manufactured by the company Plastoza, S. A of the State of Mexico, whose descriptions PLANAT $180 \times 1000 / 100(1.80 \mathrm{~m}$ wide, $1000 \mathrm{~m}$

\begin{tabular}{|c|c|}
\hline Factor A \% moisture in the manure & Factor B manure bed \\
\hline Level A1 control (as it comes from the barn) & $\begin{array}{c}\text { Level B1 at } 1 \mathrm{~m} \text { from the } \\
\text { surface }\end{array}$ \\
\hline Level A2 25\% humidity & Level B2 buried $25 \mathrm{~cm}$ \\
\hline Level A3 50\% humidity & Level B3 buried at $50 \mathrm{~cm}$ \\
\hline
\end{tabular}

Table 2: Factors established in the experimental site.

\begin{tabular}{|c|c|}
\hline Treatments & Factor A and B \\
\hline T1 (A1B1) & Control+piles at $1 \mathrm{~m}$ of the surface \\
\hline T4 (A1B2) & Control+piles buried at $25 \mathrm{~cm}$ \\
\hline T7 (A1B3) & Control+piles buried at $50 \mathrm{~cm}$ \\
\hline T2 (A2B1) & $25 \%$ humidity+piles at $1 \mathrm{~m}$ of the surface \\
\hline T5 (A2B2) & $25 \%$ humidity+piles buried at $25 \mathrm{~cm}$ \\
\hline T8 (A2B3) & $25 \%$ humidity+piles buried at $50 \mathrm{~cm}$ \\
\hline T3 (A3B1) & $50 \%$ humidity+piles at 1 of the surface \\
\hline T6 (A3B2) & $50 \%$ humidity+piles buried at $25 \mathrm{~cm}$ \\
\hline T9 (A3B3) & $50 \%$ humidity+piles buried at $50 \mathrm{~cm}$ \\
\hline
\end{tabular}

$\mathrm{T}$ : One additional experimental unit without plastic was established to compare all treatmments

Table 3: Nine treatments to determine temperature at different depths of manure piles.

\begin{tabular}{|c|c|c|c|}
\hline \multicolumn{4}{|c|}{ Distribution of the treatments } \\
\hline A1B1 1 & A3B1 3 & A2B1 2 & A1B2 4 \\
\hline A2B12 & A1B1 & A1B24 & A3B26 \\
\hline A3B1 3 & A2B2 5 & A3B2 6 & A2B2 5 \\
\hline A1B2 4 & A3B2 6 & A2B2 5 & A3B3 9 \\
\hline A2B25 & A1B24 & A3B39 & A1B37 \\
\hline A3B2 6 & A2B3 8 & A1B3 7 & A3B2 8 \\
\hline A1B37 & A3B39 & A2B38 & A3B13 \\
\hline A2B3 8 & A1B3 7 & A3B1 3 & A1B1 1 \\
\hline Bloque I & Bloque II & Bloque III & Bloques IV \\
\hline A3B3 9 & A2B1 2 & A1B1 1 & A2B1 2 \\
\hline
\end{tabular}

Table 4: Sketch showing the distribution of the treatments with their corresponding repetitions. 
Citation: Garcia AB, Salazar-Sosa E, Robles MAG, Anguiano JL, Garcia AAV, et al. (2018) Solarisation Piles and their Impact on the Removal of Pathogenic Microorganisms. Agrotechnology 7: 176. doi: 10.4172/2168-9881.1000176

Page 4 of 7

long, 100 microns thick and transparent and has the characteristic of being without albedo).

Spatial analysis: The temperatures in the different treatments and repetitions of manure piles were sampled. The temperatures were recorded by means of analog thermometers at two different operating depths (0-7.5 and 7.5-15); for the months of July, August, September and October.

Statistic analysis: The General Lineal Model (GLM) statistical method was used with the help of the SAS 9 program.

\section{Interpolations}

Once the temperature data were recorded, interpolations were made to generate continuous surfaces in Raster format. Due to the fact that in nature, physical and biological variables generally show an important spatial heterogeneity [28], this does not mean that it is impossible to find a distribution pattern. On the contrary, in most cases, there is a spatial continuity between the different locations. The previous one precise statement the use of local interpolation methods (Geostatistics) to determine continuous surfaces for the analytical variables, which was carried out once the screen digitization was completed.

\section{Microbiological analysis}

Sample taking: Solarized manure samples were taken (treatments) and not solarized (control) according to NOM-004-SEMARNAT-2002, in the all experimental unit, samples of solarized manure were taken, in each stratum or depth of exploitation of the piles $(0-7.5 \mathrm{~cm}, 7.5-15 \mathrm{~cm})$; to determine bacteria, fungi, giardia, criptosporidium and temperatures. All sample of the manure was taken collecting the manure in ziploc plastic bags, identifying the sample with a marker in the part outside of the bag, to be transferred to the microbiology laboratory of the ESBUJED for immediate sowing in the corresponding culture medium.

Statistical analysis: The General Lineal Model (GLM) statistical method was used with the help of the SAS 9.0.

Identification program of bacteria: Weight of $5 \mathrm{~g}$ of the sample of solarized bovine manure (treatments) and non-solarized (control), to be suspended in $100 \mathrm{ml}$ of sterile saline solution at $0.85 \%$ (SSE), to then take $100 \mu \mathrm{l}$ of the suspension, which were poured and were distributed with boiling beads on the surface of boxes with Luria Agar (A.L) and Methylene Blue Eosin Agar (EM B). The boxes were incubated for 24 to 48 hours at $35^{\circ} \mathrm{C}$ and the microbial load count expressed in more probable numbers (NMP) was per formed by means of an electronic counter. Finally, the isolation of the colonies present in the boxes was carried out, according to their colonial morphological diversity (Figure 1).

Identification program of Fungi: Weigh $5 \mathrm{~g}$ of the sample, to be suspended in $100 \mathrm{ml}$ of $0.85 \%$ Sterile Saline Solution (SSE), to then
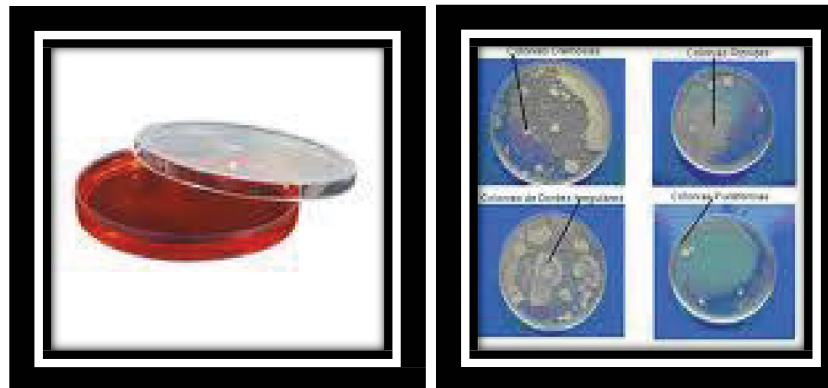

Figure 1: Incubation in Petri dishes with different agar. take $100 \mu$ of the suspension, which were poured and distributed with boiling beads on the surface of boxes with Agar for Dextrose (APD). The boxes were incubated for 1 to 8 days at $25^{\circ} \mathrm{C}$ and the microbial load count expressed in Most Probable Numbers (NMP) was performed by means of an electronic counter. Finally, the isolation of the colonies present in the boxes was carried out, according to their colonial microbiological diversity (Figure 2).

Taxonomic identification tests: The identification of the bacteria present in the solarized and non-solarized manure (control) was carried out according to the bacterial identification criteria of [29] through the following tests:

Gram-positive bacillus:

- Colonial morphology and gram staining

Gram-negative bacillus:

- Colonial morphology and gram staining

- $\quad$ Growth in EMB medium

- $\quad$ Media metabolism, SIM, LIA, TSI, MIO and Simmon Citrate

For the taxonomic identification of the fungi, the colonial morphology of the fungi, direct observation under the microscope and observation of reproduction structures were taken into account [18]. Giardia and cryptosporidium were determined by identification in a fluorest microscopy in the laboratory.

\section{Results and Discussion}

\section{Temperature determination of treatments}

The behavior of the registered temperatures was of descending way, showing that the month of July registered the maximum temperatures, presenting an average of $67^{\circ} \mathrm{C}$ to $0-15 \mathrm{~cm}$ and of $65^{\circ} \mathrm{C}$ to $15-30-\mathrm{cm}$ depth, the month of October was the less hot month The temperatures of the month of July were higher compared to the month of October; because the month of July is in the summer season and October in the fall, as expected that July would report the maximum temperatures. According to the Global Lineal Model (GLM) multiple regression statistical analysis, the null hypothesis of uniform temperature distribution in the different treatments with a $\mathrm{Pv}=0.0001$ is rejected. The treatments had two conditions, the first condition refers to the percentage of moisture present in the piles; the second condition refers to manure beds.

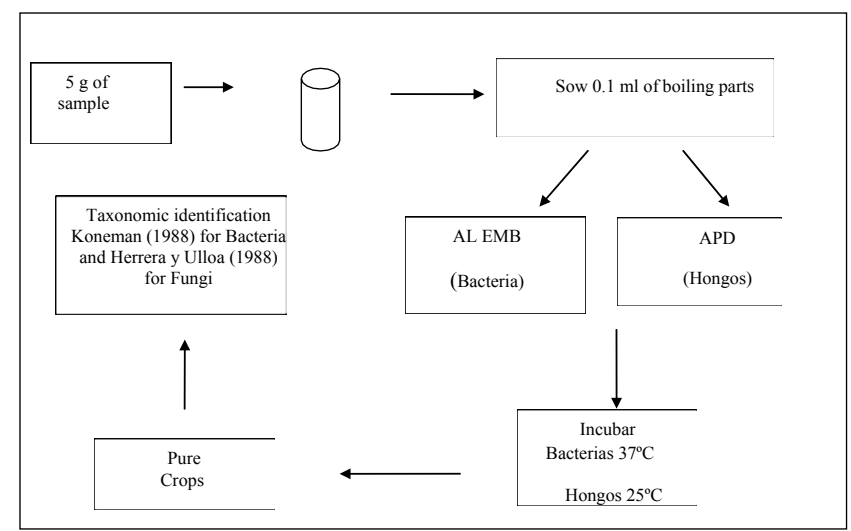

Figure 2: Isolation and identification diagram of microorganisms of solarized bovine manure. 
Citation: Garcia AB, Salazar-Sosa E, Robles MAG, Anguiano JL, Garcia AAV, et al. (2018) Solarisation Piles and their Impact on the Removal of Pathogenic Microorganisms. Agrotechnology 7: 176. doi: 10.4172/2168-9881.1000176

Page 5 of 7

\section{Interpolations}

General analysis: The minimum temperatures were located with an orientation towards the left side of the pile; with respect to the behavior in the maximum temperatures they were preferably placed with an orientation towards the right side of the pile. Because solar radiation orientation was higher in this side, the temperatures showed a behavior with a greater oscillation with a centre orientation to the right of the pile of manure, placing in these orientations the maximum temperatures and the minimum temperatures were oriented in the lower left part of the pile (Figures 3 and 4).

Microbiological analysis: Determination of treatments According to the Global Lienal Model (GLM) multiple regression statistical analysis, the null hypothesis of microbial load is rejected in the different treatments with a $\mathrm{Pv}=0.0001$, with the mean of the control being 131.5 NMP statistically different according to the SNK mean test. With an average of 1.8 NMP treatments (Figure 5), the statistical analysis shows that the treatments had significant differences with a $\mathrm{Pv}=0.0001 \%$. The means test to the grouped treatments of three; the first group corresponded to T8, which presented the average of $1.75 \mathrm{NMP}$; the second group corresponds to the treatments: T2, T5 and T7 showing an average of $0.25 \mathrm{NMP}$ and finally the third group corresponds to the treatments: T1, T3, T4, T6 and T9 presenting an average of $0.00 \mathrm{NMP}$. These last treatments are considered the best when not showing any bacterial growth, having as a characteristic in common that three of them have $50 \%$ humidity (T3, T6, T9, T4 and T1). These treatments prove to be the most effective since the temperatures generated by these months were the highest according to the average test performed previously. The information obtained coincides with the results of $[18,30]$, found that many soil pathogens do not survive during exposure 6 hours at $47^{\circ} \mathrm{C}$ and 2 to 4 weeks if the temperature is $37^{\circ} \mathrm{C}$.

\section{Identification and Conclusion}

According to the results shown the presence of Escherichia coli,
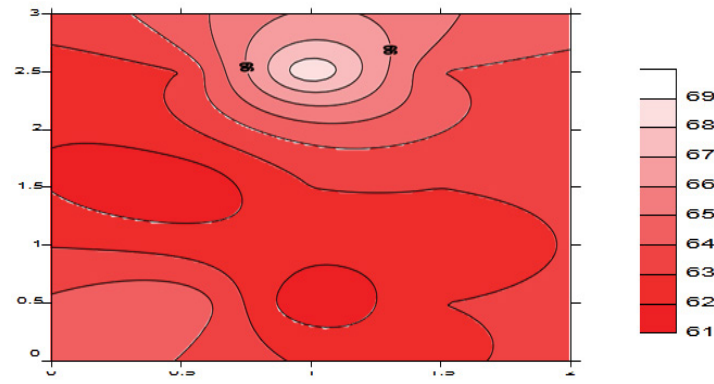

Figure 3: Temperature in the stack at $0-15 \mathrm{~cm}$ depth.

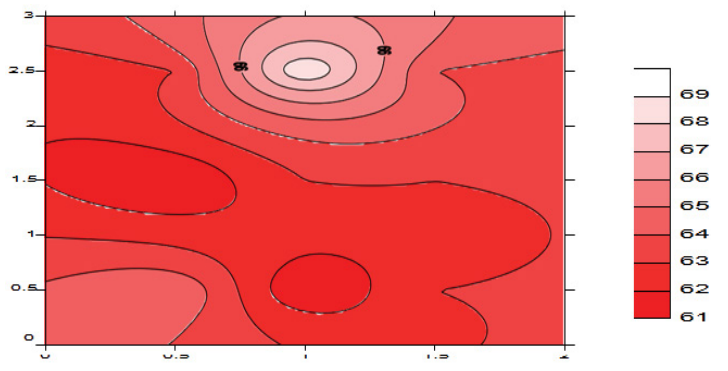

Figure 4: Temperature in the pile at $15^{\circ} \mathrm{C}-30^{\circ} \mathrm{C}$.
F. interobacteriaceae, Enterobacter sp., Bacillus sp., Mucor sp. and $F$. saccharomycetaceae, were found in manure without solarizing (control). The foregoing is corroborated in studies by [31] indicate that the bacterium Escherichia coli 0157 survive a wide range of moisture levels. In the present study, by not performing the solarisation technique, in the presence of microorganisms is reported, the survival of organisms present in the manure have been studied by $[32,33]$ in pollinaza. In the samples obtained from solarized manure, no pathogenic microorganisms were found; however for the T2, T5, T7 and T8 the presence of Bacillus sp. The results of the $[34,35]$ trial. Stapleton and De Vay [28] indicate that thermotolerant organisms such as Bacillus sp. and thermophilic soil usually survive the soil solarisation process. On the other hand $[36,37]$ indicate in composting studies, that the temperatures reached were of $60^{\circ} \mathrm{C}$ and they were sustained during three weeks, these were enough to kill these miroorganimos, However, there is the possibility of an undetectable population growth, due to the heterogeneity of composting in the piles. Similar patterns were reported by [30] in a study to determine the temperature that inactivates the movement of the bacterium salmonella enteritidis PT4 notes that this occurred at $60^{\circ} \mathrm{C}[35]$ notes that the E. coli bacterium that developed in culture medium and under laboratory conditions, its inactivity occurred after 15 minutes at temperatures of $60^{\circ} \mathrm{C}$ (Table 5).

According to Killham [29] the following bacteria were found for the prokaryotic domain, corresponding to the order Enterobacteriales and Family: Enterobacetriaceae, for Escherichia coli and genus for species and genus only. Enterobacter $s p$ and Bacillus $s p$. Studies carried out by

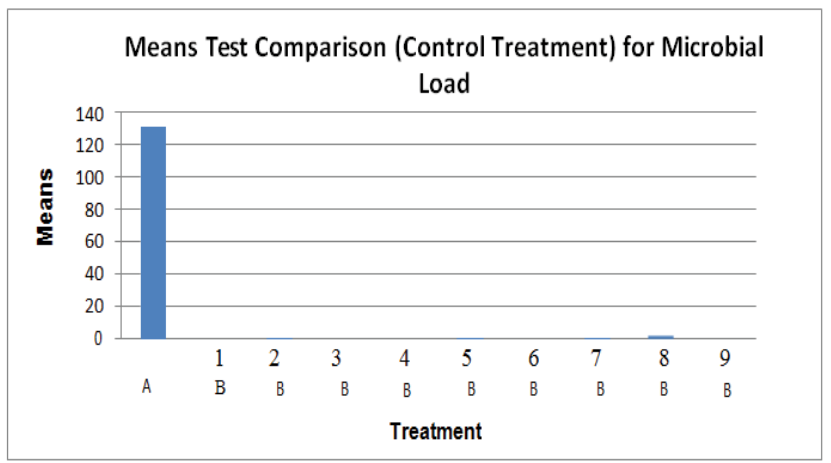

A= Aditional pile without solarization

Figure 5: Comparative stocking test (Treatments-Control) for microbial load. $\begin{array}{llllllllllll}1 & 2 & 3 & 4 & 5 & 6 & 7 & 89 & 10 & 11\end{array}$

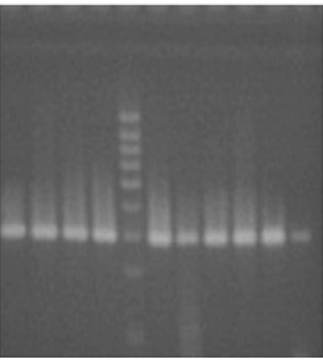

$4 \mathrm{~A}$ $\begin{array}{llllllllllll}1 & 2 & 3 & 4 & 5 & 6 & 7 & 8 & 9 & 10 & 11\end{array}$

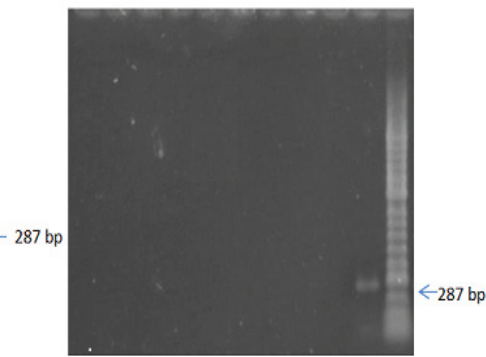

BA
$11=G e n e$ invA of salmonela introduced to compare treatments before and after solarization

Figure 6: Amplification of invA gene of Salmonella from different manure treatments before $(4 A)$ and after $(4 B)$ solarization process. 
Citation: Garcia AB, Salazar-Sosa E, Robles MAG, Anguiano JL, Garcia AAV, et al. (2018) Solarisation Piles and their Impact on the Removal of Pathogenic Microorganisms. Agrotechnology 7: 176. doi: 10.4172/2168-9881.1000176

Page 6 of 7

\begin{tabular}{|c|c|c|c|c|c|c|c|c|c|c|}
\hline CEPA Microbiologicas & $A=$ Sample without plastic & $\mathbf{T} 1$ & T 2 & T 3 & T 4 & T 5 & T 6 & $\mathbf{T} 7$ & T 8 & T 9 \\
\hline Cryptosporidium sp. & * & & & & & & & & & \\
\hline Giardia sp. & * & & & & & & & & & \\
\hline Enterobacteriaceae & * & & & & & & & & & \\
\hline Escherichia coli & * & & & & & & & & & \\
\hline Enterobacter sp. & * & & & & & & & & & \\
\hline Bacillus sp. & * & & * & & & * & & * & * & \\
\hline Mucor sp. & * & & & & & & & & & \\
\hline Saccharomycetaceae & * & & & & & & & & & \\
\hline
\end{tabular}

Table 5: Microorganisms present in manure solarized and without solarizing

Strapleton and De Vay [28], indicate that in a study to evaluate the effects of solarisation on pathogenic fungi of the soil, they found that at temperatures of $49^{\circ} \mathrm{C}$ the pathogenic fungi were drastically reduced, whereas the actinomycetes, fungi thermos tolerant and Bacillus subtilis, Staphylococcus spp, survived these temperatures and increased their population density after solarisation. Stapleton [28], who mention that soil solarisation is more selective in relation to thermophilic and thermotolerant biota and actinomycetes can survive and even thrive under soil solarisation. To corrobarte the information found mainly in Salmonella bacteria using PCR, results indicated that in all treatments, the gen (invA) of these bacteria was removed after solarisation process (Figure 6) [36-46].

\section{References}

1. Cueto WJA, Castellanos R, Figueroa VU, Cortes J, Reta S, et al. (2005) Sustainable use of organic waste in agricultural production systems. Technical brochure SAGARPA INIFAP. p: 51.

2. Figueroa VUR, Faz CJA, Cueto W, Marquez R (2003) Optimization of the use of bovine manure in forage crops Research Report. La Laguna Experimental Field. CIRNOC-INIFAP. p: 6.

3. Castellanos RJ (1982) The use of steyrol in agriculture. Memories of the First International Cycle Torreon Coah Mexico. p: 36.

4. Cassanello ME, Nuñez CA (1999) Rational management of pathogenic soil in greenhouses by solarisation. PROVA Project / Faculty of Agriculture of PREDEg 2: 13-145.

5. Castellanos RJ (1985) The physical environment of the soil and its modification through the application of dry matter. Mexican Society of Soil Science Didactic Themes Series.

6. Castellanos RJZ, Uvalle BJX, Aguilar SA (2000) Manual of interpretation of soil and water analysis. Institute of Training for Agricultural Productivity (INCAPA) San Miguel de Allende Guanajuato Mexico.

7. Miller FC (1992) Composting as a process based on the control of ecologically selective factors applications in agricultural and environmental management. Soil Microbial Ecology: 515-544

8. Castellanos RJZ (1984) Manure for agricultural use in the lagunera region. Technical Brochure No 1 La Laguna Experimental Agricultural Field. CIANINIA 19.

9. Garcia Perez R (2001) Organic fertilizers and earthworms in organic animal production VI forum of organic agricultural and livestock production. Chapingo Autonomous University. Chapingo, Mexico.

10. Reta SDG, Cueto WJA, Figueroa VU (2004) Effect of the application of manure and compost on fodder maize in two sowing systems research report. INIFAP Experimental Field La Laguna.

11. Lampkin N (1998) Comparison between organic and mineral fertilization for soil fertility levels, crop macronutrient concentrations, and yield. Agronomy $\mathrm{J}$ 99: 973-983.

12. Food and Agriculture Organization Statistics (FAOSTAT) (2005) Statistics of the Organization of the United Nations for Agriculture and Food.

13. Soils, fertilizers and organic matter (1998) Agricultural Library Second Edition IDEA BOOKS SA Barcelona Spain. pp: 25, 38, 98.
14. Salazar S, Beltran M, Fortis HM, Leos R, Cueto W, et al ( 2003) Nitrogen mineralization in the soil and production of fodder maize with three farming systems. Rev Terra 21: 569-575.

15. Salazar S, Cirilo V, Hector I, Trejo E, Oscar R (2016) Application Management and Decomposition of Cattle Manure.

16. Fermor TR, Wood DA, Lynch JM (1989) Microbiological processes in compost Int Symp Compost Prod use San Michele All Adige Italy. pp: 282-300.

17. Jimenez Diaz F (1995) Solarization an alternative for the management of phytopathogens that survive in the soil. Revista Mexicana de Fitopatologia 13 : 76-87.

18. Pullman GS, DeVay JE, Garber RH, Wein Hold AR (1981) Soil solarisation Effects on Verticillium wilt of cotton and soil borne populations of Verticillium dahlia, pythium spp. Rhizoctonia solani and Thielaviopsis basicola. Phytopathology 71: 954-954.

19. Doyle (2003) Thermal inactivation of Escherichia coli $0157 \mathrm{H} 7$ in cow manire compost. J Food Prot 66: 1771-1777.

20. Official Gazette of the Federation of October 31, 2000. NOM-EM-037FITO-2000.

21. Official Gazette of the Federation of February 7, 2006. Law of Organic Products

22. Official Journal of the European Communities (2002) FDA, USDA and CFSAN, 1999.

23. Mexican Certificate of Products and Ecological Processes SC (CERTIMEX) (2005) Rules for the production, processing and marketing of Ecological products. Oaxaca Oax Mexico.

24. Official Gazette of the Federation of April 23, 1997. NOM-037-FITO-1995.

25. Stapleton J, De Vay JE (1984) Thermal components of soil solarization as related to changes in soil and root microflora and increased plant growth response. Phytopathol 74: 255-259.

26. Juarez PC, Gastelum RF, Paplomatas RJ, De Vay JE (1991) Therma sensitivity of three species of Phytophthora and the effect of soil solarization on their survival. Plant Dis 75: 1160-1164.

27. Application rules and organic product legislation. Inorganic Fertilizers and Plasticulture. Faculty of Agriculture and Animal Husbandry (faz-ujed).

28. Stapleton J, De Vay JE (1982) Effect of soil solarisation on population of selected soilborne microorganism and growth of deciduous fruit tree seedlings. Phytopathology 72: 323-326.

29. Killham K (1993) Soil microbial ecology applications in agriculture environment management. J Agri Sci 121: 293

30. Bollen GJ, Parker CA, Rovira AD, Moore KJ, Wong PT, et al. (1985) Ecology and management of soli borne pathogens. St Paul. American Phytopathological Society. pp: 191-193

31. Berry ED, Miller DN (2005) Cattle feedlot soil moisture and manure content Impact on Escherichia coli O157. J Environ Qual 34: 656-663.

32. Bourbos VA, Skoudrindakis MT (1994) Soli solarization for the control of Verticillium wilt of greenhouse tomato. Phytoparasitica 24: 277-280.

33. Gamlielt A, Hadar E, Katan J (1989) Soil solarization to improve yield of gypsophila in monoculture systems. Acta Horticulturae 255: 131-138.

34. Bohn HL, McNeal BL, GA O'Connor (1993) Soil chemistry. Ed Limusa Mexico DF. 
Citation: Garcia AB, Salazar-Sosa E, Robles MAG, Anguiano JL, Garcia AAV, et al. (2018) Solarisation Piles and their Impact on the Removal of Pathogenic Microorganisms. Agrotechnology 7: 176. doi: 10.4172/2168-9881.1000176

35. Brock TD (1978) Thermophylic microorganisms and life at high temperatures. Springer- Verlag, New York, United States of America. pp: 72-79.

36. Maher Y, Maot O, Rawitz E, Katan J (1984) Temperature and humidity regimen in soil mulched whit transparent polyethylene. Soil Sci Soc Amer J 48: 362-367.

37. Mahrer $Y$ (1979) Prediction of soil temperature of a soil mulched with transparent polyethylene. J Appl Metrerol 18: 1263-1267.

38. Tortarolo MF, Pereda M, Palma M, Arrigo NM (2008) Influence of the inoculation of microorganisms on the temperature in the composting process. Agronomy Faculty 26:41-50

39. Garcia-Moral FJ (2004) Application of geostatistics in environmental sciences. Ecosystems 131: 78-86.

40. Garibaldi A, Guillino ML (1991) Soil Solarization in Southern European Countries With Emphasis on Soil Borne Diseases Control of Protected Crops.
41. Guidance to minimize microbial risk in foods, in the case of fruits and vegetables (1998) Washington, DC.

42. Jiang XJ, Morgan MP, Johnston K, See Hoef JM, Krivoruchko K, et al. (2001) Using Arc Gis Geostatistical Analyst. ESRI 300.

43. Lopez M, Diaz AE, Martinez RE, Valdez CR (2001) Organic fertilizers and thei effect on physical and chemical soil properties and maize yield. Sci Information System: 293-299.

44. Ristaino JB, Perry KB, Wu Y (1997) Advances in temperature predictive models for soil solarisation. Food and Agriculture Organisation of United States.

45. Schloeder CA, Zimmerman NE, Jacobs MJ (2001) Comparison of methods for interpolating soil properties using limited data. Soil Sci Soc Am J 65: 470-479.

46. Uribe M, Chavez SN, Orozco HG, Espino VS (2004) Larger production of alfalfa fertilizing the soil with biosolids. Technical Brochure No 18. INIFAP Experimental Field Delights. 